\title{
THE ABSORPTION, TISSUE DISTRIBUTION AND EXCRETION OF DI- $n$-OCTYLTIN DICHLORIDE IN RATS
}

\author{
ANDRE H. PENNINKS, LUUK HILGERS and WILLEM SEINEN
}

Department of Pharmacology, Pharmacy and Toxicology, Faculty of Veterinary Sciences, State University of Utrecht, Biltstraat 172, Building A9, $3572 \mathrm{BP}$, Utrecht (The Netherlands)

(Received August 14th, 1986)

(Accepted December 3rd, 1986)

\section{SUMMARY}

In this study the absorption, tissue distribution and excretion of ${ }^{14} \mathrm{C}$ labeled di- $n$-octyltin dichloride $\left(\left[{ }^{14} \mathrm{C}\right]\right.$ DOTC) in rats were investigated after oral and intravenous (i.v.) administration. Although after i.v. administration with $1.2 \mathrm{mg}\left[{ }^{14} \mathrm{C}\right] \mathrm{DOTC} / \mathrm{kg}$ body weight the tissue radioactivity was about $3-4$ times higher than after oral administration with $6.3 \mathrm{mg}\left[{ }^{14} \mathrm{C}\right] \mathrm{DOTC} / \mathrm{kg}$ body weight, the relative tissue accumulation was found to be the same after the oral and i.v. dosage. The highest amount of radioactivity was found in liver and kidney, and to a lesser degree in adrenal, pituitary and thyroid glands. The lowest activity was recovered from blood and brain. No selective accumulation was observed in thymus, although it has been reported that thymus atrophy is the most sensitive parameter of DOTC toxicity in rats. For all tissues a time dependent decrease in radioactivity was found, except for kidney. The excretion of radioactivity in feces and urine was determined after a single i.v. or oral dose of 1.2 and $2 \mathrm{mg}\left[{ }^{14} \mathrm{C}\right]$ DOTC, respectively. After i.v. administration most of the radioactivity was excreted in the feces which was characterized by a biphasic excretion pattern. In orally treated rats more than $80 \%$ of the radioactivity was already excreted in the feces during the first day after administration. This indicated that only a small part of the DOTC was absorbed, which was calculated to be approximately $20 \%$ of the dose. Similar half-life values of 8.3 and 8.9 days were obtained from the fecal excretion of radioactivity after the i.v. and oral administration, respectively. The urinary excretion of radioactivity appeared to be independent of the body burden, since the daily amount of radioactivity excreted in urine was nearly the same independent of the route of administration as well as the time after administration.

Address all correspondence to: Dr. A.H. Penninks, Department of Pharmacology, Pharmacy and Toxicology, Biltstraat 172, Building A9, 3572 BP Utrecht, The Netherlands. 
Key words: Organotin compounds; Di-n-octyltin dichloride; Absorption; Tissue distribution; Excretion; Thymus atrophy

\section{INTRODUCTION}

Dialkyltin compounds are industrially applied in 3 major areas: (1) as stabilizers in polymers; (2) as biocides; and (3) as catalysts [1,2]. For heat and light stabilization of polyvinylchloride (PVC) plastics, that accounts for approximately $70 \%$ of the organotin production [3], mainly di- $n$-butyltin and di- $n$-octyltin derivatives are used. In food grade PVC wrappings and containers, especially di- $n$-octyltin maleate and di- $n$-octyltin $S, S^{\prime}$-bis(isooctylmercapto-acetate) are permitted to use in the U.S.A. [4] .

In previous studies it was shown that the oral toxicity of dioctyltin compounds was low and they even had been considered to be biologically inactive [5-7]. More recent studies reported that in rats the main action of di-n-octyltin dichloride (DOTC) and other dialkyltin compounds, was on the immune system [8-10]. Feeding studies with DOTC at dietary levels of 50 and $150 \mathrm{ppm}$ resulted in a dose-related reduction in the weights of thymus, spleen and lymph nodes, as result of a lymphocyte depletion in the cortex of the thymus and thymus dependent areas in the peripheral lymphoid organs. These effects resulted in an immune suppression, in particular of the cell mediated immunity [10-13]. Studies on the mechanisms involved in the selective effects of dialkyltins on thymus revealed a direct lymphocytostatic and/or cytotoxic effect of these compounds on the intrathymic rapidly dividing cell population [14-16].

Little information is available on the distribution of dialkyltins in the body. A selective accumulation in thymus, as suggested by Seidler et al. [17] would be the simplest explanation for their activity on thymus. However, in rats dosed i.v. with $8 \mathrm{mg}$ DOTC/ $\mathrm{kg}$ body weight Hennighausen et al. [18] found only a minor concentration of $2.4 \mu \mathrm{g}$ tin/g thymus, whereas much higher concentrations of 31 and $51 \mu \mathrm{g}$ tin/g tissue were noted in liver and spleen at day 1 after administration.

In the present study the tissue distribution of radioactivity was studied in male rats up to 7 days after both single i.v. or oral administration of $\left[{ }^{14} \mathrm{C}\right]$ DOTC. Furthermore, the excretion of radioactivity was followed for 25 days, and calculations were made to estimate the absorption of DOTC from the gastrointestinal tract.

\section{MATERIALS AND METHODS}

\section{Chemicals}

${ }^{14} \mathrm{C}$-labeled di- $n$-octyltin dichloride $\left[{ }^{14} \mathrm{C}\right]$ DOTC, with an activity of 33.2 $\mathrm{mCi} / \mathrm{mmol}(79.8 \mu \mathrm{Ci} / \mathrm{mg})$ was obtained from Schering $\mathrm{AG}$, Berlin. It had a chemical purity of more than $98 \%$ and was contaminated with about $1 \%$ monooctyltintrichloride (MOTC) as found with TLC-analysis. Both for oral 
and intravenous administration of $\left[{ }^{14} \mathrm{C}\right]$ DOTC, the desired amount of compound was dissolved in a mixture of absolute ethanol, Tween 80 and phosphate buffered physiological saline $(5: 2: 93$, by vol.). The test compound was first dissolved in ethanol and then mixed with Tween 80 ; finally, while the mixture was swirled on a whorl mixer, the saline was added slowly. The scintillation fluid used for radioactivity counting in the collected organ-, tissue-, and excreta samples consisted of $5 \mathrm{~g}$ 2,5-diphenyl oxazole (PPO) and $20 \mathrm{mg}$ 2,2'-p-phenylene-bis-(5-phenyl oxazole (POPOP)/litre reagent grade toluene (Merck AG, Darmstad, FGR).

\section{Animals and diet}

Specific pathogen-free Wistar-derived rats (WU-CPB) (Central Institute for the breeding of Laboratory animals, TNO Zeist, The Netherlands) were housed in individual metabolism cages, designed to collect urine and feces separately. Room temperature was maintained at $23 \pm 2^{\circ} \mathrm{C}$ and the relative humidity at $50-60 \%$ with a $12 \mathrm{~h}$ light/dark cycle. Diet (Muracon, from Trouw \& Co., Putten, The Netherlands) and tapwater were constantly available.

\section{Tissue distribution studies}

The tissue distribution of radioactivity was determined in male rats weighing 80-100 $\mathrm{g}$ following a single i.v. or oral (by gavage) administration of 1.2 and $6.3 \mathrm{mg}\left[{ }^{14} \mathrm{C}\right]$ DOTC/kg body weight, respectively. Groups of 3 animals were killed by decapitation at $1,2,4$ and 7 days after the administration, and blood was collected in heparinized tubes. The animals were dissected immediately to sample and weigh the organs and tissues. Duplicate or triplicate $50-100-\mathrm{mg}$ samples of most organs and tissues were cut, weighed, and transferred to liquid scintillation vials to examine their content of radioactivity. For the smaller organs, e.g. adrenal, pituitary glands etc. the radioactivity of the total organ was measured. To each vial $1 \mathrm{ml}$ of the tissue solubilizer Soluene 350 (Packard Instruments, Packard Dekker B.V., The Netherlands) was added and allowed to stand for one night at $50-60^{\circ} \mathrm{C}$. After solubilization, samples of liver, kidney, heart, lung and blood were decolourized by adding $0.5 \mathrm{ml}$ of isopropanol followed by 0.5 $\mathrm{ml}$ of a $30 \%$ solution of $\mathrm{H}_{2} \mathrm{O}_{2}$, to reduce colour quenching. After adding $10 \mathrm{ml}$ scintillation fluid to each vial the content of radioactivity was determined in a Mark II (Nuclear Chicago) liquid scintillation counter and corrected for background. Counting efficiency was determined by the external standard technique. The tissue radioactivity was expressed in dpm/mg tissue.

From these data the relative accumulation index of radioactivity in each of the organs and tissues was calculated according to the equation: $R_{t}=\left(C_{t} / H_{t}\right)$. In this equation $R_{t}$ stands for the relative accumulation of radioactivity at time $t$ (days); $C_{t}$ for radioactivity in $\mathrm{dpm} / \mathrm{mg}$ tissue at time $t$, and $H_{t}$ for the radioactivity in $\mathrm{dpm} / \mathrm{mg}$ tissue which was calculated by dividing the total radioactivity in the sampled organs and tissues by their total weight at time 
TABLE I

DISTRIBUTION OF RADIOACTIVITY IN RAT TISSUES ON DAYS 1, 2, 4 AND 7 FOLLOWING A SINGLE ORAL ADMINISTRATION OF $6.3 \mathrm{mg}\left[{ }^{14} \mathrm{C}\right] \mathrm{DOTC} / \mathrm{kg}$ BODY WEIGHT ${ }^{\mathrm{a}}$

\begin{tabular}{|c|c|c|c|c|c|c|c|c|}
\hline \multirow[t]{3}{*}{ Tissue } & \multicolumn{8}{|c|}{ Tissue concentrations of ${ }^{14} \mathrm{C}$-activity } \\
\hline & \multicolumn{4}{|c|}{$\mathrm{dmp} / \mathrm{mg}$ tissue } & \multicolumn{4}{|c|}{ Relative accumulation index ${ }^{b}$} \\
\hline & 1 & 2 & 4 & 7 & 1 & 2 & 4 & 7 \\
\hline Thymus & 23 & 19 & 16 & 15 & 0.37 & 0.41 & 0.44 & 0.63 \\
\hline Peripheral lymph nodes & 64 & 43 & 28 & 22 & 1.06 & 0.85 & 0.77 & 1.01 \\
\hline Spleen & 75 & 60 & 40 & 31 & 1.19 & 1.15 & 1.48 & 1.40 \\
\hline Heart & 38 & 33 & 24 & 20 & 0.59 & 0.59 & 0.64 & 0.93 \\
\hline Skeletal muscle & 20 & 17 & 13 & 9 & 0.31 & 0.31 & 0.35 & 0.44 \\
\hline Lungs & 50 & 34 & 28 & 19 & 0.78 & 0.72 & 0.77 & 0.87 \\
\hline Liver & 679 & 553 & 309 & 145 & 10.63 & 10.40 & 8.40 & 6.53 \\
\hline Kidneys & 144 & 130 & 133 & 134 & 2.85 & 2.51 & 3.77 & 5.95 \\
\hline Pancreas & 41 & 40 & 27 & 20 & 0.65 & 0.80 & 0.73 & 0.91 \\
\hline Adrenals & 103 & 104 & 64 & 53 & 1.65 & 1.95 & 1.87 & 2.36 \\
\hline Thyroid gland & 86 & 55 & 46 & 28 & 1.42 & 1.14 & 1.26 & 1.37 \\
\hline Pituitary gland & 95 & 84 & 43 & 34 & 1.46 & 1.74 & 1.24 & 1.64 \\
\hline Parotid gland & 30 & 28 & 18 & 13 & 0.48 & 0.59 & 0.50 & 0.61 \\
\hline Submaxillary glands & 31 & 26 & 24 & 21 & 0.48 & 0.53 & 0.68 & 0.93 \\
\hline Perirenal adipose & 27 & 38 & 40 & 25 & 0.45 & 1.17 & 1.49 & 1.12 \\
\hline Inguinal adipose & 25 & 37 & 29 & 21 & 0.41 & 0.93 & 1.11 & 1.01 \\
\hline Epidydimal adipose & 31 & 37 & 36 & 30 & 0.53 & 0.88 & 1.05 & 1.34 \\
\hline Testis & 14 & 10 & 14 & 8 & 0.23 & 0.21 & 0.29 & 0.38 \\
\hline Brain & 6 & 6 & 9 & 5 & 0.09 & 0.13 & 0.21 & 0.27 \\
\hline Blood & 13 & 19 & 9 & 8 & 0.21 & 0.28 & 0.21 & 0.26 \\
\hline
\end{tabular}

${ }^{a}$ All values are the mean of 3 animals.

${ }^{\mathrm{b}}$ Relative accumulation index, $R_{t}=\left(C_{t} / H_{t}\right)$, for explanation see Material and Methods.

\section{TABLE II}

THE RELATIVE WEIGHT OF THYMUS, LIVER AND KIDNEYS 4 DAYS AFTER A SINGLE ORAL OR i.v. DOSE OF $\left[{ }^{14} \mathrm{C}\right]$ DOTC $^{\mathbf{a}}$

\begin{tabular}{|c|c|c|c|c|c|}
\hline \multirow[t]{2}{*}{ Route } & \multirow{2}{*}{$\begin{array}{l}\text { Dose } \\
(\mathrm{mg} / \mathrm{kg} \text { body wt })\end{array}$} & \multirow{2}{*}{$\begin{array}{l}\text { Body wt } \\
(\mathrm{g})\end{array}$} & \multicolumn{3}{|c|}{ Relative organ weight in $\mathrm{g} / 100 \mathrm{~g}$ body wt. } \\
\hline & & & Thymus & Liver & Kidney \\
\hline \multirow[t]{2}{*}{ Oral } & - & $119 \pm 3$ & $0.36 \pm 0.02$ & $4.83 \pm 0.09$ & $1.04 \pm 0.04$ \\
\hline & 6.3 & $117 \pm 4$ & $0.30 \pm 0.04 *$ & $4.71 \pm 0.10$ & $1.08 \pm 0.03$ \\
\hline \multirow[t]{2}{*}{ i.v. } & - & $102 \pm 4$ & $0.33 \pm 0.03$ & $4.80 \pm 0.14$ & $1.08 \pm 0.01$ \\
\hline & 1.2 & $98 \pm 2$ & $0.19 \pm 0.02 * *$ & $4.93 \pm 0.24$ & $1.07 \pm 0.04$ \\
\hline
\end{tabular}

\footnotetext{
a Results are the mean \pm S.D. of 3 animals.
}

$* P<0.05 . * * P<0.005$. 
TABLE III

DISTRIBUTION OF RADIOACTIVITY IN RAT TISSUES ON DAYS $1,2,4$ AND 7 FOLLOWING A SINGLE i.v. DOSE OF $1.2 \mathrm{mg}\left[{ }^{14} \mathrm{C}\right] \mathrm{DOTC} / \mathrm{kg}$ BODY WEIGHT ${ }^{\mathrm{a}}$

\begin{tabular}{|c|c|c|c|c|c|c|c|c|}
\hline \multirow[t]{3}{*}{ Tissue } & \multicolumn{8}{|c|}{ Tissue concentrations of ${ }^{14} \mathrm{C}$-activity } \\
\hline & \multicolumn{4}{|c|}{$\mathrm{dmp} / \mathrm{mg}$ tissue } & \multicolumn{4}{|c|}{ Relative acc. index ${ }^{b}$} \\
\hline & 1 & 2 & 4 & 7 & 1 & 2 & 4 & 7 \\
\hline Thymus & 66 & 84 & 102 & 110 & 0.26 & 0.42 & 0.64 & 0.93 \\
\hline Peripheral lymph nodes & 217 & 160 & 114 & 90 & 0.87 & 0.81 & 0.72 & 0.76 \\
\hline Spleen & 300 & 234 & 154 & 113 & 1.18 & 1.18 & 0.97 & 0.96 \\
\hline Heart & 213 & 163 & 110 & 81 & 0.84 & 0.82 & 0.69 & 0.69 \\
\hline Skeletal muscle & 86 & 71 & 54 & 39 & 0.34 & 0.35 & 0.34 & 0.33 \\
\hline Lungs & 182 & 157 & 115 & 83 & 0.72 & 0.79 & 0.72 & 0.70 \\
\hline Liver & 2598 & 1822 & 1433 & 1092 & 9.98 & 9.23 & 9.01 & 9.01 \\
\hline Kidneys & 831 & 764 & 687 & 687 & 3.28 & 3.87 & 4.35 & 5.82 \\
\hline Pancreas & 156 & 155 & 130 & 125 & 0.62 & 0.78 & 0.82 & 1.06 \\
\hline Adrenals & 510 & 445 & 315 & 256 & 2.01 & 2.24 & 1.98 & 2.18 \\
\hline Thyroid gland & 243 & 219 & 128 & 122 & 0.95 & 1.11 & 0.82 & 1.03 \\
\hline Pituitary gland & 232 & 199 & 252 & 112 & 0.91 & 0.99 & 1.01 & 0.94 \\
\hline Parotid gland & 106 & 98 & 87 & 77 & 0.42 & 0.50 & 0.55 & 0.65 \\
\hline Submaxillary glands & 221 & 202 & 170 & 161 & 0.87 & 1.02 & 1.07 & 1.35 \\
\hline Perirenal adipose & 94 & 94 & 66 & 77 & 0.37 & 0.47 & 0.42 & 0.65 \\
\hline Inguinal adipose & 83 & 87 & 62 & 47 & 0.32 & 0.44 & 0.38 & 0.40 \\
\hline Epidydimal adipose & 93 & 87 & 67 & 53 & 0.36 & 0.44 & 0.42 & 0.44 \\
\hline Testis & 48 & 51 & 48 & 49 & 0.19 & 0.26 & 0.30 & 0.42 \\
\hline Brain & 26 & 31 & 30 & 38 & 0.10 & 0.15 & 0.19 & 0.24 \\
\hline Blood & 34 & 36 & 23 & 15 & 0.13 & 0.18 & 0.14 & 0.13 \\
\hline
\end{tabular}

${ }^{a}$ All values are the mean of 3 animals.

${ }^{\mathrm{b}}$ Relative accumulation index, $R_{t}=\left(C_{t} / H_{t}\right)$, for explanation see Materials and Methods.

$t$ (see Table I and III). The weights of blood, muscle and fat tissues were estimated to contribute to 8,45 and $8 \%$ of the total body weight, respectively [19].

\section{Excretion studies}

Groups of 3 male rats weighing 100-120 g were given a single i.v. or a single p.o. dose (by gavage) of $1.2 \mathrm{mg}$ and $2 \mathrm{mg}\left[{ }^{14} \mathrm{C}\right] \mathrm{DOTC} / \mathrm{kg}$ body weight, respectively. Then for 25 days urine and feces of each animal were daily collected separately and their radioactivities were measured. Triplicate $50-\mu 1$ aliquots of urine from the individual animals were transferred to scintillation vials and $1 \mathrm{ml}$ Soluene-350 was added. The fecal samples of the individual animals were dried at $50-60^{\circ} \mathrm{C}$, weighed, and ground to a fine powder with a mortar and pestle. Then triplicate 10-20-mg samples from the individual animals were transferred to scintillation vials and rehydrated with $0.1 \mathrm{ml}$ water $(1 \mathrm{~h})$ before adding $1 \mathrm{ml}$ Soluene-350. The vials of urine and fecal samples were closed and incubated overnight at $50-60^{\circ} \mathrm{C}$. To reduce 
colour quenching the fecal samples were treated in the same way as described in the "tissue distribution studies". After adding $10 \mathrm{ml}$ of scintillation fluid to the vials, radioactivity was determined by liquid scintillation counting. The total daily excretion of radioactivity in urine and feces of the individual animals were calculated from the daily amount of urine and feces and expressed in dpm/day.

\section{Statistical analysis}

Student's $t$-test [20] was used to calculate the significance of differences.

\section{RESULTS}

\section{Tissue distribution}

Oral administration. The distribution of radioactivity in various rat tissues at selected time intervals following a single oral administration of $6.3 \mathrm{mg}\left[{ }^{14} \mathrm{C}\right]$ DOTC $/ \mathrm{kg}$ body weight is presented in Table $\mathrm{I}$. The highest concentration of radioactivity/mg tissue was found in liver and kidney. Also in the endocrine organs adrenals, thyroid glands and pituitary gland, the radioactivity/mg tissue was somewhat higher than in the other organs and tissues determined. Although thymic atrophy is the most sensitive criterion of DOTC toxicity in rats, as it is also shown by the decrease in relative thymus weight in this study (Table II), low levels of radioactivity were observed in this organ. In spite of the lipophilic character of DOTC no accumulation was found in the adipose tissues, although from day 1 to day 2 a slight increase of the radioactivity was found there.

In most organs and tissues a time dependent decline in radioactivity was observed, but the relative accumulation indexes of these organs and tissues were almost constant during the 7 days experimental period, indicating equal elimination rates. In some organs and tissues such as thymus, adipose tissues and brain the elimination rate was somewhat lower, resulting in a slight increase of the relative accumulation indexes for these organs. In the liver a higher elimination velocity was observed, as is demonstrated by the time-dependent decrease of the relative accumulation index.

In kidney the total amount of activity did not decline during the experimental period, and therefore the relative accumulation index increased time-dependently.

Intravenous administration. The distribution of radioactivity in various rat tissues measured at selected time intervals following a single in travenous administration of $1.2 \mathrm{mg}\left[{ }^{14} \mathrm{C}\right] \mathrm{DOTC} / \mathrm{kg}$ body weight is given in Table III. Although higher amounts of radioactivity were recovered from the various organs, the relative tissue accumulation index showed the same pattern of distribution found upon the oral administration. The highest concentration of radioactivity $/ \mathrm{mg}$ of tissue was recovered in liver. The relative accumulation index in adipose tissues was somewhat lower than that observed after oral administration. The amount of radioactivity in thymus was low, but in contrast to the oral administration the relative accumulation index increased 


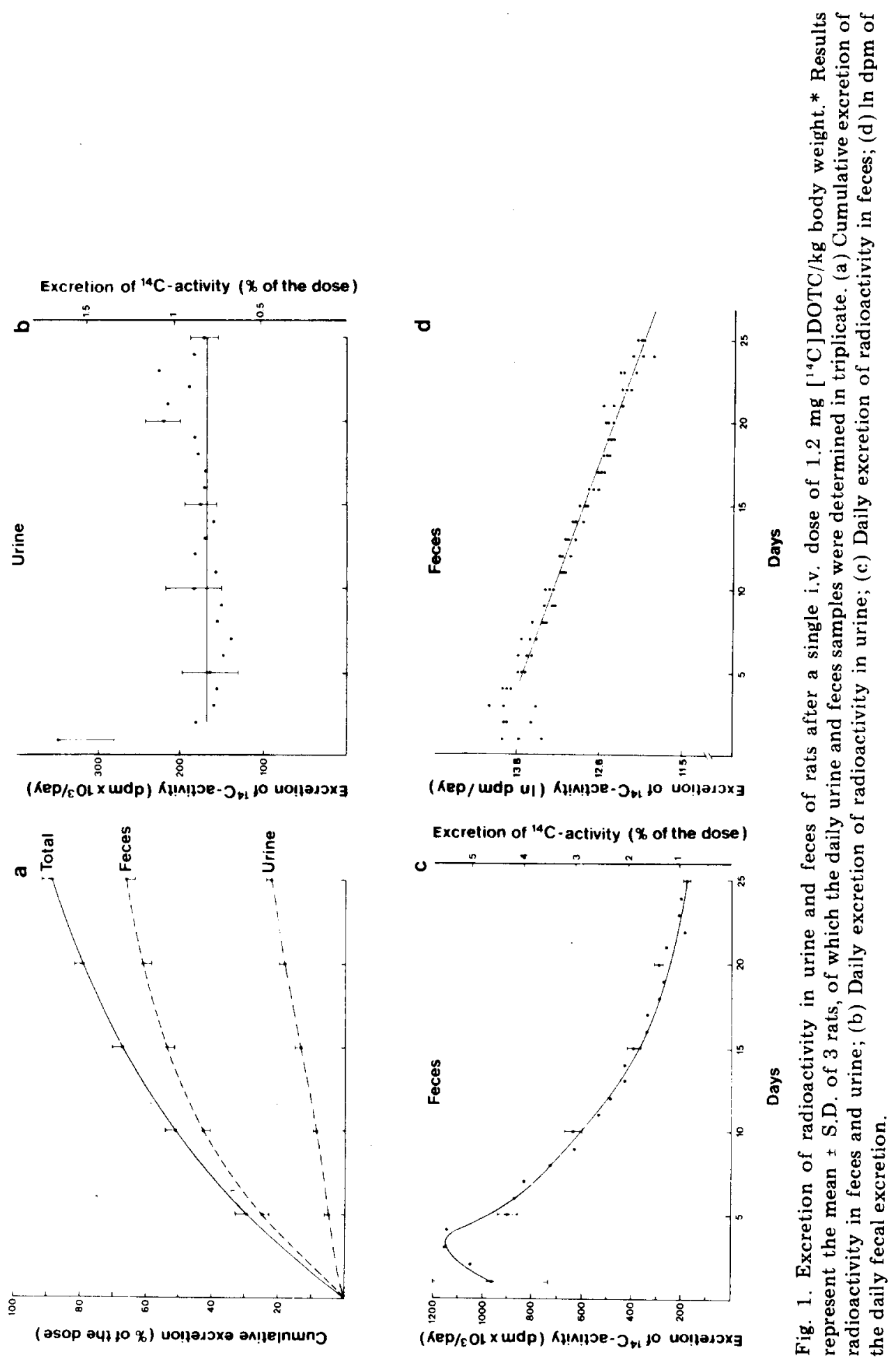


time-dependently. However, during the 7 days experimental period the absolute amount of radioactivity in thymus did not increase, whereas the thymus weight was diminished by approximately $45 \%$ (Table II).

\section{Excretion}

Intravenous administration. The cumulative excretion profile following the single i.v. administration with $1.2 \mathrm{mg}\left[{ }^{14} \mathrm{C}\right] \mathrm{DOTC} / \mathrm{kg}$ body weight is presented in Fig. 1a. During the 25 days experimental period the total recovery of radioactivity in the excreta was $88.7 \pm 2.9 \%$ of the administered dose of which $66.3 \pm 2.6 \%$ was excreted in the feces, while $22.4 \pm 2.9 \%$ was excreted in the urine. These results indicate that after i.v. administration, the major excretion of $\left[{ }^{14} \mathrm{C}\right]$ DOTC derived activity is via the feces.

The urinary excretion of radioactivity appeared to be independent of the concentration in the body (Fig. 1b). An almost constant daily amount of $(170 \pm 23) \times 10^{3} \mathrm{dpm}$ was excreted, except in the urine of day 1 where a slightly higher amount, $(346 \pm 72) \times 10^{3} \mathrm{dpm}$, of radioactivity was recovered. This may probably be due to the higher blood level of radioactivity during the first hours after i.v. administration, when $\left[{ }^{14} \mathrm{C}\right]$ DOTC is distributed throughout the body.

The fecal excretion of radioactivity was characterized by a biphasic excretion pattern (Fig. 1c). In the early phase (days $1-4$ ) the daily excretion increased, followed by the second phase (days 5-25), in which the daily excretion slowly diminished. In the second phase the excretion was dependent on the concentration in the body and followed first order kinetics. When the fecal excretion data from days 5 to 25 were plotted in $\ln$ of the dpm value as a function of time a linear relationship was observed (Fig. 1d). It is described by the equation $F(t)=14.14-0.083 t$, where $F(t)$ is the $\ln \mathrm{dpm}$ of the amount of radioactivity excreted in the feces at time $t$ (days). The half-life of $\left[{ }^{14} \mathrm{C}\right]$ DOTC derived activity in the rat was calculated to be

8.3 days $\left(t_{1 / 2}=\frac{\ln 2}{k_{1}}=\frac{0.693}{0.083}=8.3\right)$

Oral administration. The mean cumulative daily excretion of radioactivity in rat urine and feces following the single oral administration of $2 \mathrm{mg}\left[{ }^{14} \mathrm{C}\right]$ DOTC $/ \mathrm{kg}$ body weight is presented in Fig. 2a. At day 25 , a total of $10.9 \pm$ $0.6 \%$ of the administered radioactivity has been excreted in the urine, while $89.0 \pm 5.0 \%$ of the dose was excreted in the feces. At the end of the 25 days experimental period $99.9 \pm 5.1 \%$ of the orally administered radioactivity was recovered from the urinary and fecal excreta.

The daily rate of urinary and fecal excretion of radioactivity is shown in Figs. 2b,c. During the first day after administration a comparatively high amount of radioactivity was recovered from the urine, probably due to the higher blood level of radioactivity during the first day after administration when $\left[{ }^{14} \mathrm{C}\right] \mathrm{DOTC}$ is absorbed. In the following period the daily urinary 

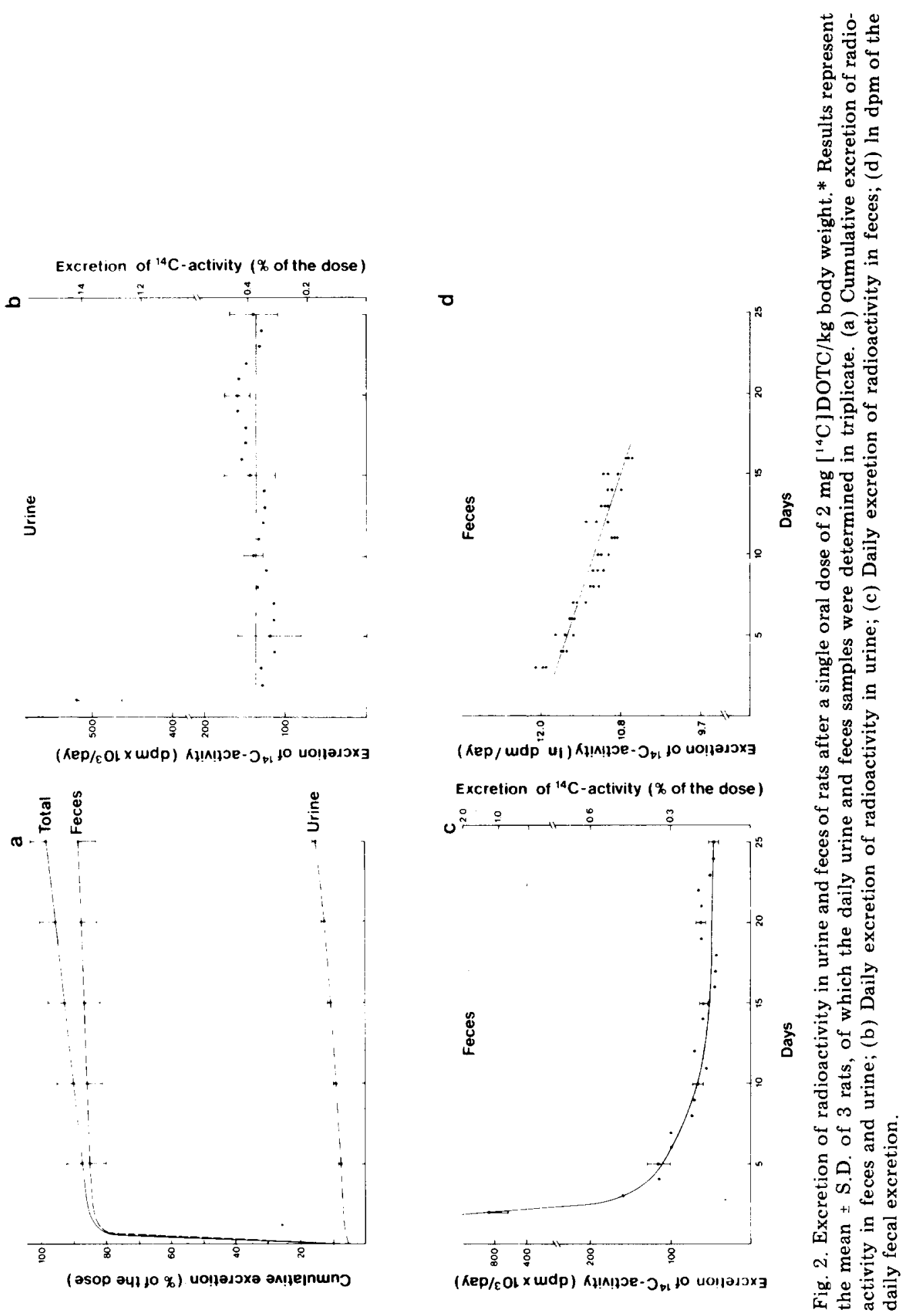
excretion of radioactivity was constant at an amount of $(138 \pm 15) \times 10^{\text {s }}$ $\mathrm{dpm}$, almost the same as found after i.v. administration $(170 \pm 23) \times 10^{3}$ dpm.

An average of $82.3 \pm 5$ and $2.2 \pm 0.5 \%$ of the administered dose was recovered in the feces excreted on days 1 and 2, respectively. From day 3 after treatment a gradual decrease in radioactivity excretion was observed, which was dependent on the concentration in the body (Fig. 2c). When the fecal excretion data were plotted in $\mathrm{ln}$ of the dpm value as a function of time a linear relationship was found from day 3 to day 16 (Fig. 2d). From this first order excretion kinetics, described by the equation $F(t)=11.97-$ $0.077 t$, where $F(t)$ is the $\ln \mathrm{dpm}$ of the amount of radioactivity excreted in the feces at time $t$ (days), the half-life for fecal excretion of 8.9 days can be calculated.

\section{Absorption}

From the fecal excretion data of the oral administration studies the absorption of $\left[{ }^{14} \mathrm{C}\right]$ DOTC from the gastrointestinal tract can be approximated. Since the amount of radioactivity recovered from the feces diminished dramatically during days 1 and 2 and thereafter gradually declined, the greater part of fecal excretion of the first 2 days will represent the amount of DOTC not absorbed from the gastrointestinal tract. From the administered oral dose of 6.3 (distribution study) and $2 \mathrm{mg}$ (excretion study) DOTC $/ \mathrm{kg}$ body weight already $84.5 \pm 5.1$ and $79.6 \pm 4.5 \%$ was recovered from the feces collected at the first 2 days, respectively. This indicates that the amounts of radioactivity absorbed will be approximately 15.5 and $20.4 \%$ of the doses, respectively. However, these values have to be corrected for the amount of radioactivity already excreted during the first 2 days from the amount which had been already absorbed in the body. Assuming that the percentages of fecal excretion from the body burden in the oral as well as i.v. studies during the first 2 days are identical, the latter being 12.1 and $9.6 \%$ of the dose (= body burden) in the 2 i.v. studies (mean value 10.9\%), the absorption was calculated as follows: absorption $=$ administered oral dose - fecal excretion $+10.9 \%$ of the absorbed amount. From this equation the absorption was calculated to be 17.4 and 22.9 in the 2 experiments.

\section{ISCUSSION}

Although DOTC selectively induces thymus involution in rats [8], the results of the tissue distribution of radioactivity clearly show that this compound does not accumulate in thymus. One day after oral or i.v. DOTC administration only 0.007 and $0.09 \%$ of the administered activities were found in this organ, respectively. The accumulation of radioactivity expressed in $\mathrm{dpm} / \mathrm{mg}$ tissue weight was even lower in thymus than in most other organs and tissues. The relative accumulation index of thymus was therefore low. Although the total amount of radioactivity in the thymus declined, the radioactivity $/ \mathrm{mg}$ tissue increased time-dependently in rats given a single i.v. 
dose of $1.2 \mathrm{mg}\left[{ }^{14} \mathrm{C}\right] \mathrm{DOTC} / \mathrm{kg}$ body weight. This is probably due to the marked reduction of thymus weight. This assumption is supported by the results of the oral administration study with $6.3 \mathrm{mg}\left[{ }^{14} \mathrm{C}\right] \mathrm{DOTC} / \mathrm{kg}$ body weight, in which the reduction of thymus weight was less pronounced and the level of radioactivity in thymus tissue did not increase. Although in rats orally dosed with $24 \mathrm{mg}\left[{ }^{14} \mathrm{C}\right.$ ] DOTC Seidler et al. [17] recovered only $0.0013 \%$ of the dose from the thymus, he suggested that the comparatively high levels of activity/mg thymus tissue might be associated with the effects on thymus. However, the comparatively high level of radioactivity in this organ might rather be the result and not the cause of thymus atrophy. By determination of inorganic tin in tissues upon DOTC exposure Hennighausen et al. [18] also found low levels in thymus. Together with the present study, these results clearly demonstrate that DOTC does not accumulate selectively in thymus.

Independent of the route of administration, the highest concentration of radioactivity was recovered from liver and kidney, and to a lesser degree in the endocrine glands, i.e. adrenals, thyroid glands and pituitary gland. The lowest concentrations of radioactivity were found in blood and brain. This suggests that DOTC is rapidly distributed and diffuses poorly into the brain. Furthermore, no selective accumulation was observed in the adipose tissues, in spite of the lipophilic character of DOTC. Although effects on thymus could be mediated by the endocrine system [21], this seems to be unlikely in case of DOTC, since despite the relatively high concentrations of radioactivity in some endocrine glands, previous studies have shown that neither a decreased growth hormone production by the pituitary nor an increased release of glucocorticosteroids by the adrenals are involved in the dialkyltin induced thymus atrophy $[8,10,16]$.

In all organs and tissues the radioactivity declined time-dependently, except in kidney. The total amount of activity in kidney was constant during the 7 days experimental period. Therefore the relative accumulation index increased time-dependently. For most other organs and tissues this index remained constant, indicating a similar elimination rate. In some organs and tissues, such as brain and adipose tissues the elimination velocity was somewhat slower resulting in slightly increased relative accumulation indexes. From the liver the elimination of radioactivity was found to be faster than in other organs and tissues, since the relative accumulation indexes decreased time-dependently, which was most pronounced after the oral administration of $\left[{ }^{14} \mathrm{C}\right]$ DOTC. Although the relative accumulation indexes of radioactivity were similar after the oral and i.v. administration, the total amount of radioactivity in the organs and tissues was much lower after the oral administration than after the i.v. administration. This will probably be due to the low absorption from the gastrointestinal tract, which was calculated to be approximately $20 \%$ of the oral dose.

From the orally administered dose more than $80 \%$ is excreted in the feces collected at the first 2 days. From day 3 after treatment the excretion of radioactivity followed first order kinetics and a half-life for fecal excretion 
of 8.9 days was established. After i.v. administration a biphasic fecal excretion pattern was noted. During the first 4 days the radioactivity excreted in the feces increased, whereas from day 5 onwards the excretion gradually declined with a half-life of 8.3 days. This biphasic fecal excretion pattern can be explained by assumption of a minimum of a two-compartment opensystem model [22]. In the first phase the removal from the central compartment to the feces is assumed to grow to an optimum as result of a subsequent delivery from the other compartments. The latter phase reflects the gradual time-dependent excretion of the compound after the distribution phase has been completed.

The daily urinary excretion of radioactivity was nearly constant during the 25 days experimental period after both oral and i.v. administration and amounted to about $150 \times 10^{3} \mathrm{dpm}$. Thus, the urinary excretion appeared to be independent of the body burden of radioactivity. This might indicate that the renal excretion is not determined by metabolism of DO'TC, which in general is dependent on the concentration of the parent compound in the body. Probably DOTC itself is excreted in urine in a constant amount, since it is extremely lipophilic and the excretion will be limited by its solubility in the blood plasma.

From metabolism studies it is known that tri- and dialkyltin compounds are oxidized, yielding various hydroxylated intermediates, which are partly destannylated because of their instability [23-26]. The liberated carbon fragments are mostly further oxidized to carbondioxide. In mice, it was observed that tri- $n$-butyltin acetate was more easily destannylated than di- $n$-butyltin acetate. In contrast to a $66 \%$ destannylation of tributyltin, only $14 \%$ of the dibutyltin was destannylated within $90 \mathrm{~h}$ after a single oral administration with 1.2 and $1.1 \mathrm{mg} / \mathrm{kg}$ body weight of those compounds, respectively [26]. Although no data are available about in vivo metabolism of DOTC it is assumed from the in vitro metabolism studies of Kimmel et a! [26], that hydroxylation and destannylation in vivo of octyl substituted organotins will be even lesser than the butyl substituted compounds. They observed that the extent of in vitro microsomal metabolism of tri- $n$-alkyltins decreased with increasing chain length. Up to butyl substituted trialkyltins, tri- di- and mono substituted intermediates were found, whereas with trioctyltins no other detectable product than trace amounts of dioctyltins were observed. These results indicate, together with the slow rate of dibutyltin metabolism observed [26], that dioctyltins are probably hardly metabolized. This is further supported by the present excretion studies in which nearly all radioactivity of the i.v. and orally administered $\left[{ }^{14} \mathrm{C}\right]$ DOTC was recovered from feces and urine. Pulmonary excretion of ${ }^{14} \mathrm{CO}_{2}$ seems therefore of minor importance, indicating that destannylation of DOTC will hardly occur. Thus, although the measurement of radioactivity is difficult to interpret with any precision as to the parent compound being measured, these observations indicate that the results of measurements will largely reflect dioctyltin concentrations and are not represented by the activity of their metabolites.

In view of one of the objectives of this study it is concluded that the 
DOTC induced selective thymus atrophy is not caused by a selective accumulation of this compound in thymus. The selectivity is therefore confined to differences in susceptibility between cell populations. The mechanism underlying this differential effect is under study.

\section{ACKNOWLEDGEMENTS}

The authors wish to thank Mrs. P.M. Punt and Mr. H.J.M. van Rooijen for their excellent technical assistance and Schering $A G$, Berlin for the generous gift of the $\left[{ }^{14} \mathrm{C}\right]$ DOTC.

\section{REFERENCES}

1 A. Ross, Industrial application of organotin compounds. Ann. N.Y. Acad. Sci., 125 (1965) 107.

2 J.G.A. Luyten, in A.K. Sawyer (Ed.), Vol. 3, Applications and Biologic Effects of Organotin Compounds, Dekker, New York, 1972, p. 931.

3 WHO, Environmental Health Criteria 15. Tin and organotin compounds: A preliminary review, Geneva, 1980.

4 W.T. Piver, Organotin compounds: Industrial application and biological investigation. Environ. Health Perspect., 4 (1973) 61.

5 J.M. Barnes and H.B. Stoner, Toxic properties of some dialkyltin and trialkyltin salts. Br. J. Ind. Med., 15 (1958) 15.

6 J.M. Barnes and L. Magos, The toxicology of organometallic compounds. Organomet. Chem. Rev., 3 (1968) 137.

7 O.R. Klimmer, The application of organotin compounds reviewed by the experimental toxicologist. Arzneim. Forsch., 19 (1969) 934.

$8 \mathrm{~W}$. Seinen and M. Willems, Toxicity of organotin compounds. I. Atrophy of thymus and thymus-dependent lymphoid tissue in rats fed di- $n$-ocytltindichloride. Toxicol. Appl. Pharmacol., 35 (1976) 63.

9 W. Seinen, J.G. Vos, I. Van Spanje, M. Snoek, R. Brands and H. Hooykaas, Toxicity of organotin compounds. II. Comparative in vivo and in vitro studies with various organotin and organolead compounds in different animal species with special emphasis on lymphocytotoxicity. Toxicol. Appl. Pharmacol., 42 (1977) 197.

$10 \mathrm{~W}$. Seinen and A.H. Penninks, Immune suppression as a consequence of a selective cytotoxic activity of certain organometallic compounds on thymus dependent lymphocytes. Ann. N.Y. Acad. Sci., 320 (1979) 499.

11 W. Seinen, J.G. Vos, R. van Krieken, A.H. Penninks, R. Brands and H. Hooykaas, Toxicity of organotin compounds. III. Suppression of thymus dependent immunity in rats fed di-n-butyltindichloride and di-n-octyltindichloride. Toxicol. Appl, Pharmacol., 42 (1977) 213.

12 W. Seinen, J.G. Vos, R. Brands and H. Hooykaas, Lymphocytotoxicity and immunesuppression by organotin compounds. Suppression of graft-versus-host reactivity, blast transformation and E-rosette formation by di- $n$-butyltindichloride and di- $n$-octyltin dichloride. Immunopharmacology 1 (1979) 343.

$13 \mathrm{~W}$. Seinen, Immunotoxicity of alkyltin compounds, in R.P. Sharma (Ed.), Immunologic Considerations in Toxicology, Vol. 1, CRC Press, Boca Raton, 1981, p. 103.

14 A.H. Penninks and W. Seinen, The lymphocyte as target of toxicity: A biochemical approach to dialkyltin induced immunosuppression, in J.W. Hadden et al. (Eds.), Advances in Immunopharmacology, Vol. 2, Pergamon Press, New York, 1983, p. 41.

15 A.H. Penninks and W. Seinen, Immunotoxicity of organotin compounds, in G.G. Gibson et al. (Eds.), Immunotoxicology, Academic Press Inc., London, 1983, p. 427. 
16 A.H. Penninks, F. Kuper, B.J. Spit and W. Seinen, On the mechanism of dialkyltin induced thymus involution. Immunopharmacology, 10 (1985) 1.

17 H. Seidler, M. Härtig and H. Woggon, Das Verhalten von ${ }^{14} \mathrm{C}-$ markiertem Di-n-octylzinndithioglycolsäure-2-äthylhexylester und Di-n-octylzinnchlorid sowie ${ }^{35} \mathrm{~S}$-markiertem Thioglykolsäure-2-äthylhexylester im Rattenorganismus. Z. Gesammte Hyg., 17 (1971) 603 .

18 G. Hennighausen, U. Karnstedt and P. Lange, Organotin concentrations in liver, spleen and thymus of rats after a single administration of di- $n$-octyltindichloride. Pharmazie, 36, H.10 (1981) 710.

19 L.S. Birnbaum, G.M. Decad and H.B. Matthews, Disposition and Excretion of 2,3,7,8tetrachlorodibenzofuran in the rat. Toxicol. Appl. Pharmacol., 55 (1980) 342.

$20 \mathrm{H}$. De Jonge, Inleiding tot de medische statistiek, Verh. Ned. Inst. Prev. Geneesk., 48 $(1960)$

21 J.G. Vos, Immune suppression as related to toxicology, CRC Crit. Rev, Toxicol,, 5 (1977) 67.

22 J.R. Gillette, The importance of tissue distribution in pharmacokinetics. in T. Toerelli et al. (Eds.), Pharmacology and Pharmacokinetics, Plenum, New York, 1974, p. 205.

23 J.E. Casida, E.C. Kimmel, B. Holm and G. Widmark, Oxidative dealkylation of tetra, tri- and dialkyltins and tetra- and trialkylleads by liver microsomes. Acta Chem. Scand., 25 (1971) 1497.

24 R.H. Fish, E.C. Kimmel and J.E. Casida, Bioorganotin chemistry: Biological oxidation of tributyltin derivatives. J. Organomet. Chem., $93(1975) C_{1}-C_{4}$.

25 R.H. Fish, E.C. Kimmel and J.E. Casida, Bioorganotin chemistry: Biological oxidation of organotin compounds, in J.J. Zuckermann (Ed.), New Chemistry and applications, American Chemical Society, Washington, D.C., 1976, p. 197.

26 E.C. Kimmel, R.H. Fish and J.E. Casida, Bioorganotin chemistry, Metabolism of organotin compounds in microsomal monooxygenase systems and in mammals. J. Agric. Food Chem., 25 (1977) 1. 